\title{
Ocena poziomu zagrożenia terroryzmem w krajach Unii Europejskiej z wykorzystaniem GTI
}

Kinga Kądziołka*

\section{Wprowadzenie}

Terroryzm jest przyczyną wymiernych strat ekonomicznych oraz ma negatywny wpływ na różne dziedziny życia międzynarodowego. Straty związane z działaniami terrorystycznymi dotyczą m.in.: ofiar ataków, strat materialnych, strat firm ubezpieczeniowych czy strat w branży turystycznej związanych ze zmniejszonym poczuciem bezpieczeństwa i lękiem przed podróżami.

Celem artykułu jest ocenienie zagrożenia terroryzmem w krajach Unii Europejskiej. Kraje te są celami ataków terrorystycznych ze względu na ich znaczenie ekonomiczne i polityczne oraz zróżnicowanie kulturowe niektórych z nich. Ponadto czynnikiem mogącym mieć wpływ na zagrożenie zamachami terrorystycznymi jest napływ migrantów do UE. Z jednej strony pojawia się zagrożenie związane z przenikaniem do Europy terrorystów, którzy mogą ukrywać się wśród uchodźców. Z drugiej strony należy brać pod uwagę możliwość działań terrorystycznych ze strony grup ekstremistycznych wspierających lub negujących politykę wobec migrantów (Wojciechowski 2018).

Do oceny zagrożenia terroryzmem w krajach Unii Europejskiej wykorzystany zostanie GTI (ang. Global Terrorism Index - indeks globalnego terroryzmu). Indeks ten jest tzw. miernikiem agregatowym, który umożliwia uwzględnienie wielu składowych mogących mieć wpływ na poziom zagrożenia terroryzmem. Mierniki agregatowe są wykorzystywane w ekonomii m.in. do oceny poziomu rozwoju społeczno-ekonomicznego (Młodak 2006, Lis 2008, Kompa 2009, Kądziołka 2016).

Kraje Unii Europejskiej zostaną podzielone - przy użyciu metody Warda na grupy obszarów podobnych pod względem zagrożenia terroryzmem. Wykorzystanie metody Warda do identyfikacji grup krajów podobnych pod względem

* Kinga Kądziołka - dr nauk ekonomicznych, Wyższa Szkoła Biznesu w Dąbrowie Górniczej, kinga_kadziolka@onet.pl. 
analizowanego zjawiska pozwoli wyeliminować problem „sztywnego" podziału obiektów (tu krajów) na 4 grupy - wg wartości średniej i odchylenia standardowego - który często pojawia się w pracach poświęconych zastosowaniu mierników agregatowych. W tym przypadku liczba grup, na które kraje zostaną podzielone, będzie uzależniona od postaci dendrogramu uzyskanego za pomocą metody Warda. Analizowane dane pochodzą z ogólnodostępnych raportów Europolu oraz australijskiego Instytutu Economics \& Peace (TE-SAT 2017, Global Terrorism Index 2017).

\section{Istota, typologia i przyczyny współczesnego terroryzmu}

Dotychczas nie opracowano jednej, uniwersalnej definicji terroryzmu. W literaturze oraz aktach prawnych funkcjonuje ich obecnie ponad 200. Wg FBI terroryzm to bezprawne użycie sity lub przemocy wobec osób lub mienia, aby zastraszyć lub wywrzeć przymus na rząd, ludność cywilna albo część wyżej wymienionych, co zmierza do promocji celów politycznych lub społecznych (Aleksandrowicz 2015, s. 27).

Bezpośrednio po zamachach terrorystycznych z 11 września 2001 r. Komisja Europejska zaproponowała definicję, zgodnie z którą zamachami terrorystycznymi są: wszelkie celowe akty popetnione przez pojedyncze osoby lub organizacje przeciw jednemu lub kilku państwom, ich instytucjom lub ludności w celu zastraszenia oraz poważnego osłabienia lub zniszczenia struktury politycznej, gospodarczej i społecznej kraju (Cegiełka 2014, s. 16).

A. Schmidt $i$ in. po przeanalizowaniu ponad 100 definicji terroryzmu wskazali na pewne często powtarzające się w nich elementy, m.in. (Aleksandrowicz 2015, s. 27-28 za: Schmidt i in. 1988, s. 12):

1. stosowanie przemocy, siły lub groźby ich użycia;

2. polityczna motywacja sprawców;

3. działanie w celu wywołania strachu, groźby;

4. chęć wywołania psychologicznych skutków i reakcji;

5. celowość i planowanie działania;

6. konflikt z obowiązującymi regułami zachowań społecznych;

7. wykorzystanie mediów w celu poszukiwania rozgłosu;

8. przypadkowy dobór ofiar;

9. wykorzystanie symboliki;

10. nieobliczalność działań sprawców;

11. ukryty charakter organizacji stosującej metody terrorystyczne.

Mimo różnorodności definicji analizowanego zjawiska, większość ekspertów zgadza się, że terroryzm oznacza użycie lub groźbę użycia przemocy, metodę walki lub strategię osiągania celów, a jego celem jest zastraszenie państwa. Jest to akt przemocy bezwzględny i niezgodny z normami humanitarnymi. Istotnym elementem strategii terrorystycznej jest też rozgłos (Aleksandrowicz 2015, s. 28). 
Oprócz mnogości definicji terroryzmu w literaturze funkcjonuje również wiele typologii tego zjawiska. B. Bolechow (2003, s. 55-56) proponuje następujący podział: terroryzm klasyczny, superterroryzm (z użyciem broni masowego rażenia) oraz cyberterroryzm (z użyciem technik informatycznych).

Przyjmując za kryterium podziału modus operandi sprawców, można stworzyć następującą typologię (Aleksandrowicz 2015, s. 33):

1. terroryzm indywidualny (zamachy przeciwko wybranym osobom),

2. terroryzm skierowany przeciwko środkom transportu,

3. wzięcie zakładników,

4. zamachy bombowe,

5. terroryzm nuklearny,

6. cyberterroryzm.

Ze względu na pojawiające się nowe metody działania sprawców przedstawiona typologia będzie ulegała zmianom i nie można jej uznać za ostateczną. Można również dokonywać podziału zjawiska m.in. na podstawie nurtów ideowych czy politycznych. W tym kontekście można mówić np. o terroryzmie nacjonalistycznym, fundamentalistyczno-religijnym, parapolitycznym. Przykładowe klasyfikacje w tym zakresie przedstawiają m.in. Ł. Sendek (2009) i T.R. Aleksandrowicz (2015). Przedstawione typologie to typologie przykładowe. Podobnie jak w przypadku definicji zjawiska, żadnego z przedstawionych podziałów terroryzmu nie można uznać za uniwersalny.

Wśród przyczyn terroryzmu wskazywane są m.in. aspekty terytorialno-etniczne, czynniki o charakterze ekonomiczno-społecznym, rola mediów, wzmożone procesy migracyjne, psychologiczne źródła terroryzmu, kwestie historyczno-polityczne, ideologiczne czy kulturowe. W wielu przypadkach zamachy terrorystyczne są efektem biedy, poczucia niesprawiedliwości, wykluczenia społecznego czy bezsilności. Czynniki te wpływają na zwiększenie frustracji i poczucia krzywdy, co przyczynia się do wzrostu agresji (Cegiełka 2014, s. 17, 33-56; Wojciechowski 2016, s. 32-35).

\section{Charakterystyka współczesnych organizacji terrorystycznych}

W przeszłości grupy terrorystyczne postrzegano jako organizacje związane z niskim poziomem ryzyka. Ich działania były „przewidywalne” - wykorzystywano głównie broń palną i bomby (Cegiełka 2014, s. 37). Obecnie istnieje ryzyko sięgnięcia przez terrorystów po broń biologiczną, chemiczną czy nuklearną.

Popularną formą współczesnego terroryzmu jest też cyberterroryzm. W literaturze funkcjonuje określenie „nowy terroryzm”. Koncepcja nowego terroryzmu zakłada pojawienie się nowych, nieznanych wcześniej lub występujacych jedynie sporadycznie cech organizacji terrorystycznych, stwarzajacych znacznie większe zagrożenie dla społeczności międzynarodowej (Bezpieczeństwo 
państwa a zagrożenie terroryzmem... 2016, s. 47). Dla terrorystów poprzedniej generacji ważny był sam zamach, a nie liczba ofiar. Oczywiście zakładano, że ofiary mogą się pojawić, jednak terroryści nie skupiali się na masowości ofiar. Liczyli się z tym, że sami mogą zginąć, ale starali się to ryzyko minimalizować. Z kolei nowy terroryzm traktuje śmierć sprawcy jako jeden z elementów zamachu (Aleksandrowicz 2015, s. 52).

Jednym z podstawowych źródeł zagrożeń jest obecnie islamski fundamentalizm. Sprawcy kierują się motywami religijnymi, a ich przekonanie o wyższości moralnej jest tak silne, że nie tylko dopuszczają się zabijania przypadkowych osób, lecz są wręcz nastawieni na masowość ofiar (Bezpieczeństwo państwa a zagrożenie terroryzmem..., 2016, s. 47). „Klasyczne” organizacje terrorystyczne XX w. zazwyczaj miały jasno określone cele polityczne, często chciały osiągnąć określony cel (np. zdobyć terytorium, autonomię, zmienić politykę rządu), a kompromis nie był wykluczony. Natomiast nowi terroryści chcą zburzyć istniejący porządek świata i ustanowić globalna wspólnotę wiernych (Aleksandrowicz 2015, s. 52-53). W takim przypadku porozumienie między stronami wydaje się niemożliwe. Cechą charakterystyczną współczesnych organizacji terrorystycznych jest sieciowość. Organizacje typu sieciowego to struktury rozproszone, elastyczne, sktadajace się z wielu elementów (węztów), którymi sa osoby lub grupy osób, wraz z odnoszacymi się do nich wzajemnymi, dwustronnymi lub wielostronnymi relacjami (Kędzierski 2014, s. 74). Są to struktury „uczące się”. Wzajemne „uczenie się" organizacji terrorystycznych prowadzi do powstania struktur, w których poszczególne elementy organizacyjne stają się coraz bardziej anonimowe, a utrata jednego z węzłów nie destabilizuje całości organizacji (Kędzierski 2014, s. 75).

Sieciowe organizacje terrorystyczne implikują zmianę strategii antyterrorystycznych. Wpływ na trudności w zwalczaniu sieci terrorystycznych ma m.in. nadmiarowość sieci, rozumiana jako dysponowanie znacznie większymi zasobami niż potrzebne do realizacji zadania oraz autonomia i ograniczenie kontaktów zewnętrznych przez ogniwa działające bezpośrednio na poziomie operacyjnym (Aleksandrowicz 2015, s. 51).

Obecnie do najbardziej aktywnych, czyli przeprowadzających największą liczbę ataków, i najgroźniejszych organizacji terrorystycznych zalicza się: Państwo Islamskie, Talibów, Boko Haram, Komunistyczną Partię Indii, Partię Pracujących Kurdystanu. Od 2008 r. wśród terrorystów wyraźnie zaczęła dominować motywacja religijna (Wojciechowski 2016, s. 37-40), jednak nie jest to charakterystyczne dla całego świata. Przykładowo w krajach Unii Europejskiej przeważają ataki o podłożu separatystycznym. W 2016 r. spośród 142 ataków terrorystycznych (przeprowadzonych, nieudanych i udaremnionych) aż 99 miało podłoże separatystyczne, a tylko 13 dżihadystyczne. Ponadto w 2016 r. nie doszło do żadnego ataku ani aresztowania na tle islamistycznym w Wielkiej Brytanii, mimo że w tym państwie zamieszkuje jedna z największych społeczności muzułmańskich w Europie (TE-SAT 2017). 


\section{Global Terrorism Index (GTI) - konstrukcja wskaźnika}

W konstrukcji wskaźnika GTI uwzględnia się następujące składowe: liczbę zamachów terrorystycznych, liczbę ofiar śmiertelnych wskutek zamachów terrorystycznych, liczbę rannych w zamachach terrorystycznych, wartość uszkodzonego mienia spowodowaną zamachami terrorystycznymi.

Poszczególnym składowym wskaźnika GTI nadawane są następujące wagi (Global Terrorism Index 2017, s. 108):

1. łączna liczba ataków terrorystycznych: 1 ;

2. łączna liczba ofiar śmiertelnych wskutek ataków terrorystycznych: 3;

3. łączna liczba rannych $w$ atakach terrorystycznych: 0,5 ;

4. łączna wartość strat materialnych w wyniku ataków terrorystycznych: 0-3.

W przypadku łącznej wartości strat materialnych waga tej zmiennej zależy od wielkości strat. Jest ona wyznaczana następująco (Global Terrorism Index 2017, s. 108):

1. 0 - nieustalona wartość strat;

2. 1 - łączna wartość strat $<1 \mathrm{mln}$ USD;

3. 2- łączna wartość strat mieści się w przedziale $1 \mathrm{mln}$ USD - 1 bln USD;

4. 3 - łączna wartość strat $>1$ bln USD.

Następnie dla każdego kraju można wyznaczyć „,niestandaryzowaną” wartość punktową odzwierciedlającą poziom zagrożenia terroryzmem $\mathrm{w}$ danym roku. Poniżej przedstawiono przykład obliczeń. Załóżmy, że w pewnym kraju w danym roku miało miejsce 21 incydentów terrorystycznych, w wyniku których śmierć poniosło 36 osób, a 53 osoby zostały ranne. Ponadto uszkodzonych zostało 20 budynków, przy czym wartość każdej ze strat mieściła się w przedziale 2-4 mln USD. Wówczas „,niestandaryzowana” wartość punktowa odzwierciedlająca poziom zagrożenia terroryzmem wyznaczana jest poprzez zsumowanie odpowiednich wartości przemnożonych przez wagi przypisane poszczególnym zmiennym (składowym konstruowanego miernika), czyli: $(121)+(3 \times 36)+$ $(0,5 \times 53)+(2 \times 20)=195,5$.

Następnie wyznaczana jest „niestandaryzowana” wartość wskaźnika GTI, jako średnia ważona „niestandaryzowanych” wartości punktowych odzwierciedlających poziom zagrożenia terroryzmem z ostatnich pięciu lat. Przyjmuje się następujące wartości wag (Global Terrorism Index 2017, s. 109):

1. rok ,początkowy": 16;

2. rok wcześniej: 8 ;

3. dwa lata wcześniej: 4;

4. trzy lata wcześniej: 2 ;

5. cztery lata wcześniej: 1 .

Przykładowo w raporcie Global Terrorism Index 2017 określono indeks globalnego terroryzmu na podstawie danych z lat: 2016 (rok „początkowy”), 2015, 2014, 2013, 2012. 
Żeby wyznaczyć ostateczną wartość wskaźnika GTI, „niestandaryzowaną" wartość wskaźnika przekształca się logarytmicznie w ten sposób, aby kraj o najwyższej wartości „niestandaryzowanej” wartości wskaźnika miał przypisaną wartość 10, a kraj o najmniejszej wartości „niestandaryzowanej” wskaźnika miał przypisaną wartość 0 , uzyskując wartości wskaźnika GTI z przedziału [0-10]. Przyjmuje się, że im wyższa wartość GTI, tym większe zagrożenie terroryzmem.

Z raportu Global Terrorism Index 2017 wynika, że największymi wartościami GTI w 2016 r. charakteryzowały się następujące kraje: Irak (10), Afganistan $(9,441)$, Nigeria $(9,009)$, Syria $(8,621)$, Pakistan $(8,4)$, Yemen $(7,887)$, Somalia $(7,654)$, Indie $(7,534)$, Turcja $(7,519)$, Libia $(7,256)$ (Global Terrorism Index 2017, s. 10). Z kolei w Unii Europejskiej GTI osiągnął najwyższą wartość w przypadku Francji $(5,964)$.

\section{Identyfikacja krajów UE podobnych pod względem wskaźnika GTI}

Według statystyk Europolu spośród 142 incydentów terrorystycznych (rozumianych jako ataki przeprowadzone, nieudane i udaremnione), które miały miejsce w 2016 r. w krajach Unii Europejskiej, 99 miało podłoże separatystyczne. Do ponad połowy incydentów (76) doszło w Wielkiej Brytanii. Ataki przeprowadzały następujące ugrupowania: ETA, Nowa Irlandzka Armia Republikańska, Front Narodowego Wyzwolenia Korsyki czy Galicyjski Ruch Oporu. Według danych Europolu incydenty związane $\mathrm{z}$ terroryzmem islamskim stanowią niewielką część incydentów terrorystycznych w krajach UE. Przykładowo w 2016 r. w krajach UE miało miejsce 13 incydentów o podłożu dżihadystycznym. Jednocześnie w wyniku tych właśnie zamachów zginęło ponad 95\% ofiar wszystkich zamachów terrorystycznych przeprowadzonych w Unii Europejskiej w 2016 r. (TE-SAT 2017).

W niniejszym artykule skoncentrowano się na ocenie zagrożenia terroryzmem w krajach Unii Europejskiej z wykorzystaniem wskaźnika GTI, co umożliwi ocenienie zagrożenia terroryzmem $\mathrm{z}$ uwzględnieniem wielu składowych. Tabela 1 przedstawia wartości indeksu globalnego terroryzmu wyznaczone na podstawie danych z lat 2012-2016 zgodnie z opisaną w poprzedniej części artykułu metodą. Dane te pochodzą z raportu Global Terrorism Index 2017. W raporcie tym przedstawione są wartości GTI dla 163 krajów, w których mieszka 99,7\% ludności świata. Dane dotyczące wartości wskaźnika GTI dla Malty i Luksemburga nie były dostępne, więc kraje te zostały pominięte w analizie. 
Tabela 1. GTI w krajach UE

\begin{tabular}{|r|l|}
\hline Kraj & GTI \\
\hline Francja & 5,964 \\
\hline Wielka Brytania & 5,102 \\
\hline Niemcy & 4,917 \\
\hline Belgia & 4,656 \\
\hline Grecja & 4,139 \\
\hline Szwecja & 3,756 \\
\hline Irlandia & 3,141 \\
\hline Włochy & 2,75 \\
\hline Holandia & 2,412 \\
\hline Finlandia & 2,341 \\
\hline Cypr & 1,894 \\
\hline Czechy & 1,889 \\
\hline Hiszpania & 1,701 \\
\hline Austria & 1,522 \\
\hline Dania & 1,512 \\
\hline Bułgaria & 1,178 \\
\hline Węgry & 0,835 \\
\hline Estonia & 0,461 \\
\hline Polska & 0,384 \\
\hline Słowacja & 0,23 \\
\hline Chorwacja & 0,029 \\
\hline Litwa & 0 \\
\hline Łotwa & 0 \\
\hline Portugalia & 0 \\
\hline Rumunia & 0 \\
\hline Słowenia & 0 \\
\hline & \\
\hline & \\
\hline & \\
\hline & \\
\hline & \\
\hline & \\
\hline & \\
\hline
\end{tabular}

Źródło: Global Terrorism Index 2017.

Analizując dane z tabeli 1, można zauważyć, że w przypadku niektórych krajów wartość wskaźnika GTI jest większa niż 0, mimo że w latach 2012-2016 nie doszło w nich do żadnego ataku terrorystycznego. Dotyczy to np. Polski. Należy jednak mieć na uwadze fakt, że obywatele danego kraju mogą być ofiarami ataków terrorystycznych również w innych krajach, np. w przeprowadzonym 18 marca 2015 r. przez Państwo Islamskie zamachu w Tunisie zginęło m.in. trzech Polaków, stąd wartość GTI (którego składowymi są liczba ofiar i rannych obywateli danego kraju w zamachach terrorystycznych) dla Polski za lata 2012-2016 jest dodatnia. 
Wykorzystując metodę Warda, kraje Unii Europejskiej podzielono na grupy obszarów podobnych pod względem wartości wskaźnika GTI. Metoda Warda to jedna z metod grupowania hierarchicznego, którego wynikiem jest drzewo hierarchicznie ułożonych skupień, tzw. dendrogram. Konkretna postać dendrogramu zależy od przyjętej miary odległości określającej niepodobieństwo między grupowanymi obiektami oraz metody wyznaczania odległości między skupieniami (grupami obiektów podobnych). W metodzie Warda wykorzystuje się analizę wariancji do szacowania odległości między skupieniami. Na każdym etapie tworzenia dendrogramu spośród wszystkich możliwych do łączenia par skupień wybiera się tę, która w rezultacie łączenia da skupienie o najmniejszym zróżnicowaniu. Szczegółowo metodę tę omawia m.in. A. Stanisz (2007).

Rysunek 1 przedstawia uzyskany dendrogram ${ }^{1}$. Wyraźnie zarysował się podział krajów na trzy grupy (zaznaczony na rysunku 1 przerywaną linią), w związku z czym właśnie na tyle grup podzielono kraje UE. Do grupy pierwszej należą: Grecja, Szwecja, Francja, Belgia, Niemcy i Wielka Brytania. Przeciętna wartość wskaźnika GTI dla krajów z tej grupy wynosiła 4,756. Była to grupa krajów UE, które charakteryzowały się największym poziomem zagrożenia terroryzmem ze względu na przyjęte kryterium (wartości GTI). W drugiej grupie znalazły się: Chorwacja, Słowenia, Rumunia, Portugalia, Litwa, Łotwa, Słowacja, Estonia i Polska. Była to grupa krajów charakteryzujących się najmniejszym zagrożeniem terroryzmem. Przeciętna wartość wskaźnika GTI dla krajów z tej grupy wynosiła 0,123. Trzecia grupa to: Finlandia, Holandia, Irlandia, Włochy, Bułgaria, Węgry, Cypr, Czechy, Hiszpania, Austria i Dania. Przeciętna wartość wskaźnika GTI dla krajów z tej grupy wynosiła 1,925.

Rysunek 1. Podział krajów na grupy uzyskany metodą Warda

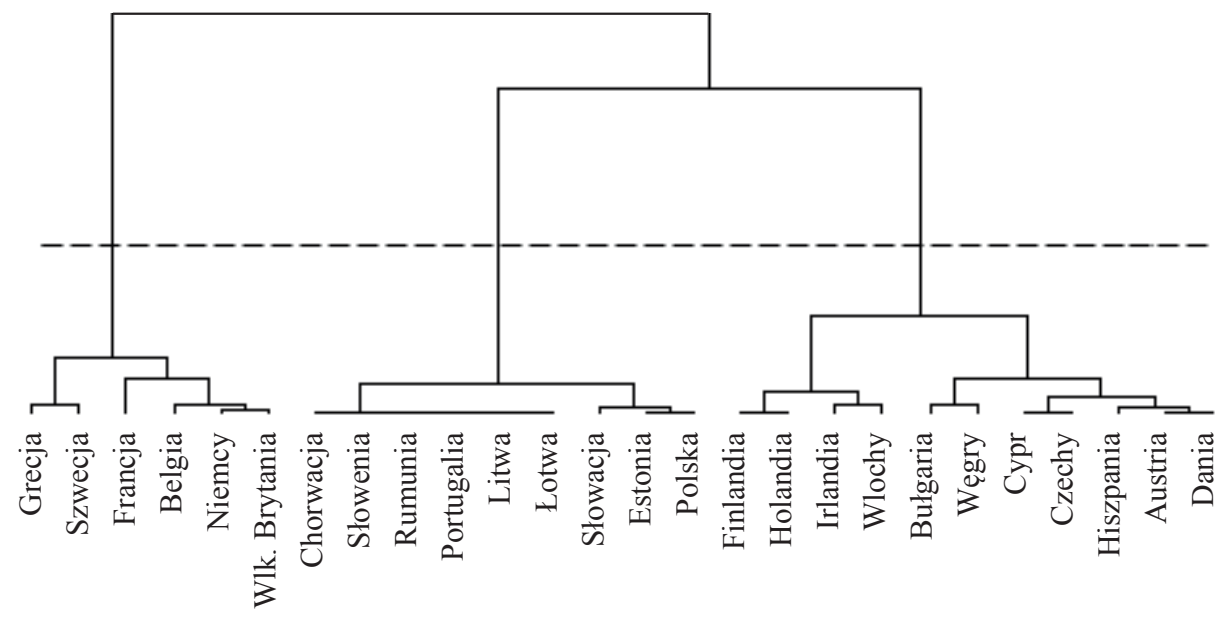

Źródło: opracowanie własne.

${ }^{1}$ Dendrogram wygenerowano wykorzystując darmowe oprogramowanie $\mathrm{R}$. 
W grupie pierwszej znajdują się kraje UE o najwyższych wartościach wskaźnika GTI wyznaczonego na podstawie danych z lat 2012-2016. Wiele organizacji terrorystycznych traktuje te kraje (szczególnie Wielką Brytanię, Francję, Niemcy, Belgię i Szwecję) jako bazę rekrutacji/szkoleń bojowników, m.in. walczących w szeregach Państwa Islamskiego, i pozyskiwania środków na działalność. Ponadto w większości krajów tej grupy żyje duża liczba emigrantów. Często są to osoby o niskiej pozycji społecznej, wywodzące się z kręgów kultury muzułmańskiej, żyjące w enklawach na obrzeżach miast (Mrózek 2014, s. 43). Sytuacja ta może przekładać się na wzrost zagrożenia zamachami terrorystycznymi. Jednocześnie każdy atak terrorystyczny będzie się przyczyniał do pogłębiania konfliktów z muzułmańską mniejszością oraz pogłębiania wykluczenia społecznego i dyskryminacji imigrantów.

Polska znalazła się w grupie krajów o najniższym zagrożeniu terroryzmem. Jednakże należy mieć na uwadze to, że położenie geopolityczne Polski oraz jej zaangażowanie w działania stabilizacyjne w Afganistanie i Iraku powodują, że może ona stać się celem zamachów terrorystycznych. Dlatego zagrożenia tego nie można lekceważyć w kontekście analizy bezpieczeństwa wewnętrznego państwa (Trubalska 2016, s. 153-154).

\section{Podsumowanie}

Terroryzm w Unii Europejskiej jest zróżnicowany pod względem ideologicznym i wbrew obiegowym opiniom nie dominują tu ataki o podłożu dżihadystycznym. W artykule przedstawiono sposób wyznaczania GTI oraz podzielono kraje Unii Europejskiej na grupy obszarów podobnych pod względem zagrożenia terroryzmem. Krajami, w przypadku których GTI osiągnął najwyższą wartość, były: Francja, Wielka Brytania, Niemcy, Belgia, Grecja, Szwecja. Polska znalazła się w grupie krajów UE o najniższym poziomie zagrożenia terroryzmem. Wykorzystanie GTI umożliwiło przeprowadzenie wielowymiarowej oceny zagrożenia terroryzmem w krajach Unii Europejskiej.

Uwzględnienie w ocenie zagrożenia terroryzmem nie tylko liczby ataków na terenie danego kraju, ale również liczby ofiar i rannych obywateli w zamachach terrorystycznych oraz wielkości strat materialnych spowodowanych atakami terrorystycznymi umożliwia rzetelniejszą ocenę skali zagrożenia niż w przypadku opierania się tylko na liczbie ataków terrorystycznych. $Z$ kolei zastosowanie aglomeracyjnych technik grupowania danych pozwala na eliminację problemu „sztywnego" podziału obiektów (tu krajów) pod względem wartości miernika agregatowego na cztery grupy według średniej i odchylenia standardowego wartości tego miernika, który to podział często jest wykorzystywany w pracach dotyczących zastosowań mierników agregatowych w ekonomii. Jednak należy mieć na uwadze to, że uzyskany podział na grupy zależy zarówno od przyjętej metody wiązania skupień, jak również od przyjętego miejsca podziału dendrogramu. 
W prezentowanym przykładzie do wiązania skupień wykorzystano metodę Warda i podzielono dendrogram wzdłuż najdłuższej gałęzi. Oczywiście nic nie stało na przeszkodzie, aby kraje podzielić na cztery grupy, uwzględniając dodatkowo podział grupy trzeciej na dwie podgrupy: Finlandia, Holandia, Irlandia, Włochy oraz Bułgaria, Węgry, Cypr, Czechy, Hiszpania, Austria, Dania. Występuje więc tu pewien element subiektywizmu zarówno w zakresie wyboru metody wiązania skupień, jak i miejsca podziału dendrogramu.

W niniejszym artykule zaprezentowano sposób konstruowania GTI, którego składowymi są: liczba ataków terrorystycznych, liczba ofiar ataków terrorystycznych, liczba rannych w atakach terrorystycznych i wielkość strat materialnych spowodowanych atakami terrorystycznymi. Konstruowany w oparciu o te składowe indeks agregatowy jest wykorzystywany w raportach Global Terrorism Index opracowywanych przez australijski Institute of Economics \& Peace do porównywania zagrożenia terroryzmem w 163 krajach. Kraje jednak zazwyczaj różnią się pod względem powierzchni i liczby mieszkańców. Stąd pojawia się pytanie: czy uwzględnienie w budowie GTI poszczególnych składowych w przeliczeniu na pewną stałą (umowną) liczbę mieszkańców nie byłoby bardziej odpowiednie?²

\section{Bibliografia}

Aleksandrowicz T.R. (2015), Terroryzm międzynarodowy, Wydawnictwo Akademickie i Literackie Wojciech Butkiewicz, Warszawa.

Bezpieczeństwo państwa a zagrożenie terroryzmem. Terroryzm na przełomie XX i XXI wieku, K. Jałoszyński, T. Aleksandrowicz, K. Wiciak (red.), Wyższa Szkoła Policji w Szczytnie, Szczytno 2016.

Bolechow B. (2003), Terroryzm wświeciepodwubiegunowym. Przewartościowania i kontynuacje, Wydawnictwo Adam Marszałek, Torun.

Cegiełka R. (2014), Terroryzm i bezpieczeństwo ekonomiczne. Wybrane zagadnienia, Agencja Wydawnicza Synergy, Warszawa.

Global Terrorism Index 2017, www.economicsandpeace.org/reports, s. 108 (data dostępu: 18.02.2018).

Kądziołka K. (2016), Analiza przestrzennego zróżnicowania rozwoju ekonomicznego Polski na poziomie powiatów, „Studia i Materiały Miscellanea Oeconomicae", nr 1.

Kędzierski M.A. (2014), Sieciowość współczesnych organizacji przestępczych funkcjonujących $w$ obszarze przestępczości zorganizowanej i terroryzmu, „Przegląd Bezpieczeństwa Wewnętrznego”, nr 10/14, s. 75.

Kompa K. (2009), Budowa mierników agregatowych do oceny poziomu rozwoju społeczno-gospodarczego, ,Zeszyty Naukowe SGGW w Warszawie: Ekonomika i Organizacja Gospodarki Żywnościowej”, nr 74.

\footnotetext{
${ }^{2}$ Np. uwzględnienie liczby ataków terrorystycznych na 1000 osób zamiast bezwzględnej liczby ataków terrorystycznych itp.
} 
Lis Ch. (2008), Wykorzystanie metod taksonomicznych $w$ analizie poziomu życia w krajach Unii Europejskiej [w:] Chrzan P., Czernik T. (red.), Metody matematyczne, ekonometryczne i komputerowe w finansach i ubezpieczeniach 2006, Wydawnictwo Uniwersytetu Ekonomicznego w Katowicach.

Młodak A. (2006), Analiza taksonomiczna w statystyce regionalnej, Wydawnictwo Difin, Warszawa.

Mrózek K. (2014), Zagrożenie Europy aktami terroryzmu - potencjalne cele, „Security, Economy \& Law", nr 4.

Schmidt A.P., Jongman A.J., Horowitz I.L. (1988), Political Terrorism: A New Guide to Actors, Authors, Concepts, Data Bases, „Theories and Literature", New Brunswick, New York.

Sendek Ł. (2009), Zjawisko terroryzmu oraz walka z nim w Unii Europejskiej, niepublikowana rozprawa doktorska, Krakowska Akademia im. A. Frycza Modrzewskiego.

Stanisz A. (2007), Przystępny kurs statystyki z zastosowaniem STATISTICA PL na przyktadach z medycyny, t. 3 - Analizy wielowymiarowe, StatSoft, Kraków.

TE-SAT 2017, European Union Terrorism Situation and Trend Report 2017, www. europol.europa.eu/sites/default/files/documents/tesat2017.pdf (data dostępu: 18.02.2018).

Trubalska J. (2016), System antyterrorystyczny w Polsce - wybrane zagadnienia, „Zeszyty Naukowe AON”, nr 4 (105).

Wojciechowski S. (2016), Zagrożenie terroryzmem $w$ XXI wieku - analiza wybranych determinantów, „Archiwum Kryminologii”, t. XXXVIII.

Wojciechowski S., Wspótczesne oblicze terroryzmu w Unii Europejskiej, Rządowe Centrum Bezpieczeństwa, rcb.gov.pl/wspolczesne-oblicze-terroryzmu-w-uniieuropejskiej (data dostępu: 15.03.2018).

\section{Streszczenie}

Celem artykułu była prezentacja sposobu konstruowania miernika GTI wykorzystywanego do wielowymiarowej oceny zagrożenia terroryzmem. Następnie przy użyciu metody Warda zidentyfikowano grupę krajów UE podobnych pod względem zagrożenia terroryzmem. Szczególną uwagę zwrócono na pozycję Polski, która z powodu aktywnego udziału w działaniach militarnych w Afganistanie i Iraku czy rozmieszczenia wojsk amerykańskich może być celem ataku terrorystycznego. Z przeprowadzonych analiz wynika, że Polska znajduje się w grupie krajów o najmniejszym zagrożeniu terroryzmem, jednak zagrożenia tego nie można lekceważyć.

Slowa kluczowe: terroryzm, GTI, metoda Warda, Unia Europejska 


\section{Summary}

Assessment of the terrorism threat level in European Union countries using the GTI index

The purpose of the article is to present the method of constructing the GTI index used for a multidimensional assessment of a terrorist threat. Next, using Ward's method, groups of EU countries similar in terms of the terrorism threat level will be identified. Particular attention was paid to the position of Poland, which due to its active participation in military operations in Afghanistan and Iraq, may be the target of a terrorist attack. The analyses show that Poland is in the group of countries with the lowest terrorism threat level. However, this threat cannot be underestimated.

Keywords: terrorism, Global Terrorism Index, Ward's method, European Union JEL: A12, D74, H56 